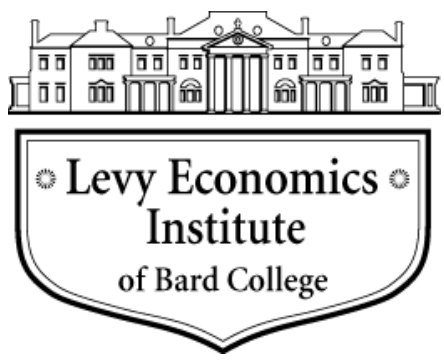

Working Paper No. 995

\title{
The Employer of Last Resort Scheme and the Energy Transition: A Stock-Flow Consistent Analysis
}

by

\section{Giuliano Toshiro Yajima*}

Sapienza University of Rome, Italy

November 2021

* I am grateful to Marco Veronese Passarella, Tracy Mott, Ricardo Summa, Giacomo Cucignatto, and Francesco Ruggeri for their useful comments to the first versions of this paper.

The Levy Economics Institute Working Paper Collection presents research in progress by Levy Institute scholars and conference participants. The purpose of the series is to disseminate ideas to and elicit comments from academics and professionals.

Levy Economics Institute of Bard College, founded in 1986, is a nonprofit, nonpartisan, independently funded research organization devoted to public service. Through scholarship and economic research it generates viable, effective public policy responses to important economic problems that profoundly affect the quality of life in the United States and abroad.

Levy Economics Institute

P.O. Box 5000

Annandale-on-Hudson, NY 12504-5000

http://www.levyinstitute.org

Copyright (C) Levy Economics Institute 2021 All rights reserved

ISSN 1547-366X 


\begin{abstract}
The health and economic crises of 2020-21 have revived the debate on fiscal policy as a major tool for stabilization and meeting long-term goals. The massive surge in unemployment, due to the economic disruption of the lockdown measures, has increased the interest in policies that target employment directly instead of trying to achieve it via a general "demand push." One of the proposals currently under debate is the job guarantee. Under such a policy the government would act as an "employer of last resort" by offering a job to everyone that is able and wants to work but cannot find a job in the private sector. This paper argues that a carefully designed scheme of direct employment and public provision by the state - addressing both the low- and high-skill workforce - can have permanent effects and promote the economy's structural transformation, in particular by fostering energy transition and a lower carbon footprint. Starting from this point, a stock-flow consistent model is developed to study the long-run effect of the job guarantee's implementation, inspired by the work of Godin (2013) and Sawyer and Passarella (2021).
\end{abstract}

KEYWORDS: Stock-Flow Consistent Models; Job Guarantee; Structural Change; Energy Transition

JEL CLASSIFICATIONS: B52; J68; Q43 


\section{INTRODUCTION}

The current health and economic crisis has revived the debate on fiscal policy as a major tool for stabilization and for meeting long-term goals. The massive surge in unemployment due to the economic disruption of the lockdown measures has increased the interest in policies that target employment directly instead of trying to achieve it via a general "demand push." At the same time, in the wake of this new normal, monetary authorities around the world have renewed their provision of liquidity to support fiscal agencies, even to the point of permanently modifying their mandate to pursue employment targets, as in the case of the US Federal Reserve (Powell 2020), or to directly finance extra government spending, as in the case of the Bank of England (BoE 2020). As a matter of fact, the European Union's response on both the fiscal and monetary sides has been partially (un)satisfactory considering the timing, the initial contradictory stance pursued by the ECB with respect to sovereign rate differentials, and in the limited scope of some backstops. Consider, for instance, the Support to mitigate Unemployment Risks in an Emergency (SURE) initiative, supporting EU member states in the emergency provision of short-term work schemes. Although useful in fighting poverty and alleviating unemployment, a traditional cash-transfer approach appears to be inadequate given the structural dimension of the current recession. One of the alternative proposals currently under debate is the job guarantee (JG) policy. Under such a policy the government should act as an "employer of last resort" (ELR), by offering a job to everyone that is able and wants to work, but cannot find a job in the private sector. The wage paid in these programs should become the minimum wage in the labor market. This job programs can be a substitute of unemployment subsidizes and would create an economic sector that increases during recessions and shrinks during the expansions. This proposal was developed by Minsky $(1965,1968,1994)$, which saw it as a necessary counterpart to the Fed's role as "lender of last resort" (LLR) in financial markets in order to stabilize an unstable economy, subject to cyclical fluctuations due to the decisions and expectations of the private sector, which are seldom driven by rational decisions (Minsky 2008). ${ }^{1}$

\footnotetext{
${ }^{1}$ Over the years, this policy proposal has received a number of criticisms, in particular on: 1) the impact on both the government budget and debt (Aspromourgos 2000; Sawyer 2003); 2) the prevailing full-employment
} 
In recent years, ELR has been increasingly used in discussion of a set of policy proposals i.e., the Green New Deal (GND), to foster the transition away from carbon fossil fuels, increase energy efficiency, and promote both environmental and social sustainability (Nersisyan and Wray 2021; Cucignatto 2021). In the version put forward by the Levy Institute (Wray et al. 2018), the backbone of this strategy will be represented by an ambitious ELR scheme targeting labor force participants with below-average skills and labor-intensive vacancies. Given the properties of these jobs, they will be devoted only to a subset of the GND projects, such as care services, small construction, and retrofitting interventions (Nersisyan and Wray 2019).

Nonetheless, it is argued that for a net annual impact on the federal government's budget of roughly 400 USD billion per year over ten years, there will be a boost to GDP of 560 USD billion annually and to employment of 19 million new workers (of which more than a fifth of the jobs will be created in the private sector). These figures are grounded in the fact that these wages will constitute a direct addition to aggregate demand, as they will be immediately spent on consumption goods. However, the authors estimate that inflation will increase only marginally in the steady state ( 0.09 percent), after a short-lived spike ( 0.74 percent) right after the implementation of the program. Finally, the ELR program should affect both the quantity and the quality of the labor force, as the increased labor demand in the economy would force hidden or disguised unemployment to shrink, whilst workers employed in the scheme would improve their productivity by receiving training. In fact, Nersisyan and Wray (2019) argue that a JG represents both a cost (in terms of wages) and a source of resources (as it provides workforce for a vast array of GND projects). ${ }^{2}$

equilibrium wage rate once the program is implemented (Seccareccia 2004); and 3) the implication for external balances (current and trade account), especially when this policy is implemented in a small, open economy (Epstein 2019; Vernengo and Perez Caldentey 2020).

${ }^{2}$ Nevertheless, there are a few critical observations that can be identified in this strategy: 1) it is not clear how ELR workers would be able to perform activities that may improve labor productivity—even with proper training and especially when these involve innovative GND-related projects (Colacchio and Forges Davanzati 2020); 2) subtracting both government and household expenditure in nonrenewable energy from the estimated costs of the various renewable energy and energy efficiency proposals as in Nersisyan and Wray (2021) may be misleadingfossil fuels do represent an invoice for some agents in the economy (and definitely a cost for the environment), but they are also a source of income (at the very least for utility and utility-linked sectors); and 3) the GND does not seem to consider any "rebounding" effect (Sorrell et al. 2007; Vivanco, Kemp, and van der Voet 2016), that is the increase in energy consumption following the improvement in energy efficiency. This represents an issue for an ELR scheme, due to the fact that by its very characteristics the JG wage bill would induce an almost one-to-one increase in aggregate consumption. 
Starting from this point, a stock-flow consistent (SFC) model is developed in order to study the effect of the implementation of a JG program inspired by the work of Antoine Godin (2013) and Malcom Sawyer and Marco Passarella (2021). The paper is composed as follows: section 2 will illustrate the choice of methodology as well as some recent developments in the SFC literature, in particular with respect to ecological models. The accounting framework and the model equations will be introduced in section 3, while section 4 will describe the different scenarios performed. Section 5 describes the results from the simulations and section 6 will summarize the main findings.

\section{THE ELR AND THE GREEN NEW DEAL}

In order to take into account some of the structural modifications that the green ELR strategy brings about in an economy with complex interactions, we will develop a multisector SFC model. SFCs are dynamic, medium-scale Keynesian macroeconometric models based on a rigorous accounting framework, which integrates the flows and stocks of a financially sophisticated economy (Carnevali et al. 2019; Godley and Lavoie 2012; Nikiforos and Zezza 2017; Caverzasi and Godin 2013). There are three reasons why we opted for this methodology.

First, the intellectual roots of this approach lie in the national account-based macroeconomic models, built in Cambridge in the 1960s by Richard Stone, whose work was successively taken up by Godley one decade later in the framework used by the Cambridge Economic Policy Group (Fetherston 1976, 1977) that Stone himself helped to develop. In the early 1990s, Godley started his collaboration with the Levy Institute, as he published a number of seminal contributions analyzing the imbalances of US trade through the lens of sectorial balance approach (Godley 1999). Since then, both this approach and in general the SFC methodology have become a fundamental component of the Levy Institute's research. Furthermore, proponents of Modern Money Theory (MMT) have been adopting SFC models to illustrate some of its core principles (Ehnts 2014, 2016; Hannsgen 2020) and critics have resorted to this framework to underline its weaknesses (Carnevali and Deleidi 2020). 
Second, it ensures the model's consistency, which Nikiforos and Zezza (2017) and Zezza and Zezza (2019) have identified in four principles: (i) flow consistency, i.e., that every flow must come from somewhere and go somewhere else-for example, in an open economy model, exports from one country are the imports of another one; (ii) stock consistency, i.e., that every asset owned by an agent (sector) is the liability of another one in the system; (iii) stock-flow consistency, i.e. that every flow implies the change in one or more stocks; and (iv) quadruple entry accounting, i.e., that every transaction is recorded four times in the accounting matrix, for instance twice as a flow of expenditure and twice as a change in assets or an increase in liabilities. The need for a rigorous accounting framework for the analysis of the GND is justified directly by Nersisyan and Wray (2019), as they argue that the estimates of the JG should avoid double counting since the buffer stock employment (BSE) represents both a financial commitment for the state and a direct addition of real resources for the economy. Moreover, it helps to shed light on some weak spots of this strategy, such as the costs of phasing out entire "brown" sectors and the rebounding effect.

Finally, SFC models have risen to prominence in recent year as the main tool for assessing the interactions between the environment and the economy from a post-Keynesian perspective. Ecological SFC works are inspired by Georgescu-Roegen's $(1971,1979)$ flow-of-funds approach to physical material transformation (and destruction/tendency toward greater entropy) linked with economic activity. Present SFC contributions answer an array of research questions; for instance, Jackson and Victor (2015) develop an SFC framework to assess whether debt generates a growth imperative After carrying out several policy experiments, both on the financial and productive system, they found out that an economy may support a steady state without having to dismantle the banking sector. Naqvi (2015), in a multisector SFC model, investigates which policies may contemporaneously deliver output growth, a more equal income distribution, and environmental sustainability. The author argues that mitigation measures - such as raising the share of renewable energy and improving both capital and energy productivity — achieve these three objectives. Dafermos, Nikilaidi, and Galanis (2018), in a less structured model from the perspective of the economic sector but with an explicit representation of the physical stock-flow balances, find that climate change increases bank 
leverage and causes an asset price deflation process. These sources of financial instability ultimately affect growth, although they may be tamed through environmentally friendly interventions by the central bank. Carnevali et al. (2021) point out that green bonds ${ }^{3}$ as the only tools for counteracting climate change may lead to paradoxical results. By using an SFC model that comprises two stylized countries, they contend that without strong coordination policies, in particular in absence of capital controls under a pure floating exchange rate regime, ecological efficiency gains may be offset by the rebounding effect i.e., higher growth rates as financial flows affect the price of the currency leading to persistent trade imbalances between the two countries. Berg, Hartley, and Richters (2015) present a more formal model integrating the SFC approach with input-output analysis in order to better investigate the interdependencies within the economy and in particular the energy sector. Deleidi, Pariboni, and Passarella (2019) adopt instead the supermultiplier approach within an SFC framework to assess the effect of an increase of autonomous government expenditure in the form of mission-oriented investment in green technologies. They assert that this policy entails a stronger multiplier effect while smoothing the rebound effects on energy consumption.

\section{THE MODEL}

For the sake of our analysis we started from two SFC contributions, namely those of Godin (2013, 2014) and Sawyer and Passarella (2021). Godin (2013) modeled a multisector economy whereby the BSE was tasked with reducing the government's and households' energy demand. He then focused on the impact of the green JG and compared these results with a standard Keynesian demand spur. Sawyer and Passarella (2021) instead built a complete SFC dynamic model to study and compare the effects of a variety of monetary and fiscal policies, including both LLR and ELR measures. Our model expands these two previous works in terms of its agents, stocks, and flows in order to fit with our research purposes. ${ }^{4}$ It is made up of seven

\footnotetext{
${ }^{3}$ Green bonds are fixed-income financial instruments designed to raise money for environmentally friendly projects. They may finance energy efficiency, pollution prevention, sustainable agriculture, fishery and forestry, the protection of ecosystems, clean transportation, and sustainable water management.

${ }^{4}$ The points of departure from each of these works in terms of policy scenario will be discussed more in depth in
} 
sectors, as shown in both the balance sheet (table 1) and transaction flow (table 2): a productive sector, comprising consumption, investment and energy firms, banks, government, the central bank, households, and a foreign sector. The main features with respect to the benchmark Godin (2013, 2014) model are: a) the presence of a more complex financial transmission mechanism, with banks able to manage the interest rate that they charge on loans; b) a foreign sector by which we can detect balance of payments problems of such a policy; and c) an explicit distinction between the government and the central bank. At variance with Sawyer and Passarella (2021), we added a utility (capital goods) sector whose output is not entirely destined for consumption but enters in the production function of both the consumption goods and the capital good (energy) sector. Lastly, the possibility for the central bank to carry out outright monetary transactions (OTMs) or quantitative easing $(\mathrm{QE})$ policies has been explicitly included in the baseline. We indeed believe that these measures constitute a structural element of modern economies and in particular financial markets. Nowadays, they constitute a new normal for monetary authorities, as they have been in place for over a decade - although with different degrees of intensity, timing, and instruments. In the next subsections, we will break down the model in each of its components and behavioral equations.

section 4. 
Table 1. Balance Sheet Matrix

\begin{tabular}{|c|c|c|c|c|c|c|c|c|c|}
\hline & Households & Firms e & Firms c & Firms k & Financial sector & Government & Central bank & Foreign sector & Sum \\
\hline Check deposits & $+m 1 h$ & & & & $-m 1 h$ & & & & 0 \\
\hline Saving deposits & $+m 2 h$ & & & & $-m 2 h$ & & & & 0 \\
\hline Bills & $+b h$ & & & & $+b b$ & $-b s$ & $+b c b$ & & 0 \\
\hline Loans & $-l h$ & $-l f_{\mathrm{e}}$ & $-l f_{\mathrm{c}}$ & $-l f_{\mathrm{k}}$ & $+l s$ & & & & 0 \\
\hline $\begin{array}{l}\text { Securities } \\
\text { Capital }\end{array}$ & $+e h$ & $\begin{array}{l}-e h \mathrm{e} \\
+k \mathrm{e}\end{array}$ & $\begin{array}{l}-e h \mathrm{c} \\
+k \mathrm{c}\end{array}$ & $\begin{array}{l}-e h \mathrm{k} \\
+k \mathrm{k}\end{array}$ & & & & & $\begin{array}{l}0 \\
\mathrm{~K}\end{array}$ \\
\hline Cash & $+h h$ & & & & & & $-h h$ & & 0 \\
\hline Advances & & & & & $-a d$ & & $+a d$ & & 0 \\
\hline Reserves & & & & & $+h b d$ & & $-h b d$ & & 0 \\
\hline Foreign Reserves & & & & & $+h f$ & & & $-h f$ & 0 \\
\hline Balance & $-V$ & $N W e$ & $N W_{c}$ & $N W k$ & $N W b$ & $N W g$ & $N W c b$ & $N W f$ & 0 \\
\hline
\end{tabular}

Source: Own elaboration. 
Table 2. Transaction Flow Matrix

\begin{tabular}{|c|c|c|c|c|c|c|c|c|c|}
\hline & Households & Firms e & Firms c & Firms k & Financial sector & Government & Central bank & Foreign sector & Sum \\
\hline Consumption & $-c$ & & $+y_{c}$ & & & $-c_{\mathrm{g}, \mathrm{c}}$ & & & 0 \\
\hline $\begin{array}{l}\text { Energy consumption } \\
\text { Govt. expenditures }\end{array}$ & $-c_{e}$ & $\begin{array}{l}+y_{\mathrm{e}} \\
+c_{\mathrm{g}, \mathrm{e}}\end{array}$ & $\begin{array}{l}-c_{c} \\
+c_{\mathrm{g}, \mathrm{c}}\end{array}$ & $\begin{array}{l}-c_{\mathrm{k}} \\
+c_{\mathrm{g}, \mathrm{k}}\end{array}$ & & $\begin{array}{l}+c_{\mathrm{g}, \mathrm{e}} \\
-g o v\end{array}$ & & & $\begin{array}{l}0 \\
0\end{array}$ \\
\hline $\begin{array}{l}\text { Investment } \\
\text { Firms' profit }\end{array}$ & $+f d f$ & $\begin{array}{l}-i d_{\mathrm{e}} \\
-f d f_{\mathrm{e}}\end{array}$ & $\begin{array}{l}-i d_{\mathrm{c}} \\
-f d f_{\mathrm{c}}\end{array}$ & $\begin{array}{l}+y_{\mathrm{k}} \\
-f d f_{\mathrm{k}}\end{array}$ & & $-c_{\mathrm{g}, \mathrm{k}}$ & & & $\begin{array}{l}0 \\
0\end{array}$ \\
\hline Taxes & $-\operatorname{tax}$ & & & & & $+\operatorname{tax}$ & & & 0 \\
\hline Banks profits & $+f b$ & & & & $-f b$ & & & & 0 \\
\hline CB profits & & & & & & $+f c b$ & $-f c b$ & & 0 \\
\hline Exports & & & $+x$ & & & & & $-x$ & 0 \\
\hline Imports & & & $-m$ & & & & & $+m$ & 0 \\
\hline Int. on check deposits & $+r m_{-1} * m 1 h_{-1}$ & & & & $-r m_{-1} * m 1 h_{-1}$ & & & & 0 \\
\hline $\begin{array}{l}\text { Int. on saving deposits } \\
\text { Int. on bills }\end{array}$ & $\begin{array}{l}+r m_{-1} * m 2 h_{-1} \\
+r b_{-1} * b h_{-1}\end{array}$ & & & & $\begin{array}{l}-r m_{-1} * m 2 h_{-1} \\
+r b_{-1} * b b_{-1}\end{array}$ & $-r b_{-1} * b s_{-1}$ & $+r b_{-1} * b c b_{-1}$ & & $\begin{array}{l}0 \\
0\end{array}$ \\
\hline Int. on loans & $-r /_{\mathrm{h},-1} * I h-1$ & $-\left.r\right|_{\mathrm{e},-1} * \mid f_{\mathrm{e},-1}$ & $-r l_{\mathrm{c},-1} * \mid f_{\mathrm{c},-1}$ & $-r l_{\mathrm{k},-1} * l f_{\mathrm{k},-1}$ & $+r l_{X,-1} * I s_{X,-1}$ & & & & 0 \\
\hline Int. on securities & $+r e_{\mathrm{x},-1} * e h_{\mathrm{x},-1}$ & $-r e_{\mathrm{e},-1} * e h_{\mathrm{e},-1}$ & $-r e_{\mathrm{c},-1} * e h_{\mathrm{c},-1}$ & $-r e_{\mathrm{k},-1} * e h_{\mathrm{k},-1}$ & & & & & 0 \\
\hline Int. on advances & & & & & $-r a_{-1} * a d_{-1}$ & & $+r a_{-1} * a d_{-1}$ & & 0 \\
\hline $\begin{array}{l}\text { Int. on reserves } \\
\text { Change in check deposits }\end{array}$ & $-\Delta m 1 h$ & & & & $\begin{array}{l}+r h_{-1} * h b d_{-1} \\
+\Delta m 1 h\end{array}$ & & $-r h_{-1} * h b d_{-1}$ & & $\begin{array}{l}0 \\
0\end{array}$ \\
\hline Change in saving deposits & $-\Delta m 2 h$ & & & & $+\Delta m<n$ & & & & 0 \\
\hline Change in bills & $-\Delta b h$ & & & & $-\Delta b b$ & $+\Delta b s$ & $-\Delta b c b$ & & 0 \\
\hline Change in loans & $+\Delta l$ & $+\Delta / f_{\mathrm{e}}$ & $+\Delta / f_{\mathrm{c}}$ & $+\Delta / f_{k}$ & $-\Delta / s$ & & & & 0 \\
\hline Change in securities & $-\Delta e h$ & $+\Delta e h_{\mathrm{e}}$ & $+\Delta e h_{\mathrm{c}}$ & $+\Delta e h_{\mathrm{k}}$ & & & & & 0 \\
\hline $\begin{array}{l}\text { Change in cash } \\
\text { Change in advances }\end{array}$ & $-\Delta h h$ & & & & $+\Delta a d$ & & $\begin{array}{l}+\Delta h h \\
-\Delta a d\end{array}$ & & $\begin{array}{l}0 \\
0\end{array}$ \\
\hline Change in reserves & & & & & $-\Delta h b d$ & & $+\Delta h b d$ & & 0 \\
\hline Change in foreign reserves & & & & & $-\Delta h f$ & & & $+\Delta h f$ & 0 \\
\hline
\end{tabular}




\subsection{Nonfinancial Firms}

Total output (equation 1) is composed of the sum of the output in the three productive sectors, namely consumption/widget (sector c), investment (sector k), and energy (sector e). The demand for the outputs of sector c (equation 2) depends upon households' consumption demand plus the (endogenous) government expenditure on this sector. Notice that it is assumed that this is the only sector that imports (exports). The $\mathrm{k}$ sector receives the invoices of investment goods from the other two sectors, plus the endogenous sectorial government expenditure (equation 3). Sector e accommodates the demand from sector $\mathrm{k}$, sector $\mathrm{c}$, households, and government (equation 4). The first two consume energy based on the energy productivity (equation 5), while for households, energy consumption is a fraction of total consumption (equation 6). The microeconomic behavior of each industry with respect to capital accumulation is quite straightforward: firms aim at a certain target of capital stock based on their previous real demand (equation 8). Depreciation allowances are a percentage of firms' capital stock and they are assumed to match amortization funds (equations 9 and 10). Hence, investment demand covers both depreciation and the deviation of current capital stock from its target, while capital grows over time in accordance with equation (12). Profits are obtained as residuals from firms' receipts minus amortization funds, wages, and interest on loans (equation 14). The latter are demanded to cover that portion of investment not funded by internal funds (amortization + retained profits, equation 7) and/or the issuance of corporate securities offered to the public (equation 18).

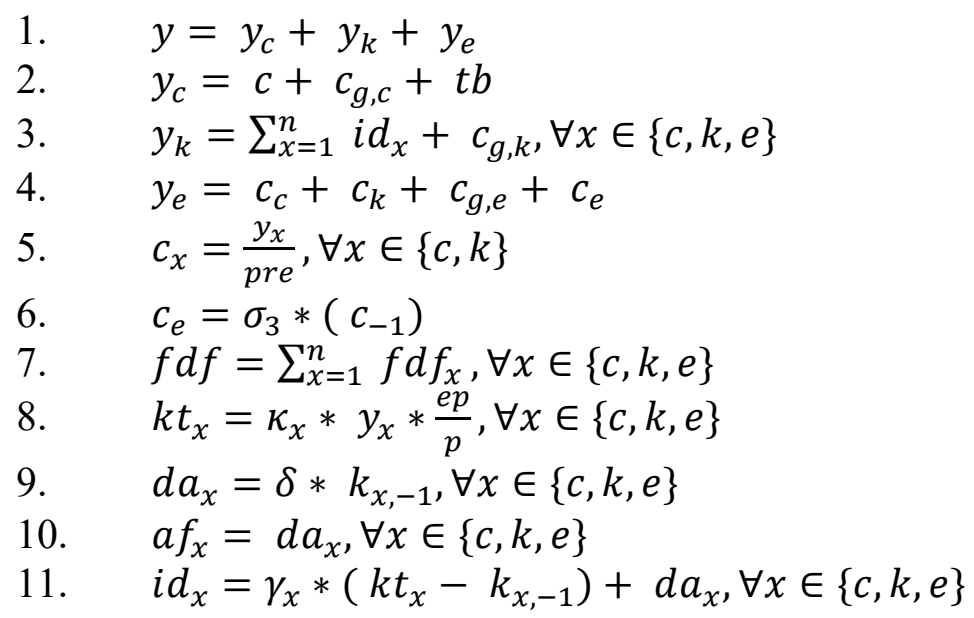


12. $k_{x}=k_{x,-1}+i d_{x}-d a_{x}, \forall x \in\{c, k, e\}$

13. $f f_{x}=y_{x}-r l_{x,-1} * l f_{x,-1}-a f_{x}-w b_{x}-c_{x}, \forall x \in\{c, k\}$

14. $f f_{e}=y_{e}-r l_{e}-1 * l f_{e}-1-a f_{e}-w b_{e}$

15. $f d f_{x}=\left(1-\right.$ thet $\left._{x}\right) * f f_{x}, \forall x \in\{c, k, e\}$

16. $f u f_{x}=$ theta $_{x} * f f_{x}, \forall x \in\{c, k, e\}$

17. $l f_{x}=l f_{x,-1}+i d_{x}-a f_{x}-f u f_{x}-\left(e s r_{x}-e s r_{x,-1}\right) * p e_{x}, \forall x \in\{c, k, e\}$

18. $e s r_{x}=e s r_{x,-1}+\operatorname{chi} * \frac{i d_{x,-1}}{p e_{x,-1}}, \forall x \in\{c, k, e\}$

\subsection{Households}

Households' disposable income is made of wages both paid in the private sector and the JG sector, plus distributed profits from firms and banks, plus interest payments on deposit and transfers from the government (equation 19). From these we should subtract the interest payments on mortgages, taxes, and public tariffs. Aggregate consumption depends upon real disposable income and wealth minus energy consumption (equation 20). Notice that we decided to specify the propensity to consume from each asset held in order to more realistically capture the decision to spend. Moreover, we endogenize the propensity to consume out of income by assuming that it behaves according to the policy and unemployment rate (equation 22). Net wealth (equation 23) is defined according to the Haig-Simmons standard (including capital gains on shares, equation 25), while gross wealth includes mortgages (equation 24). The private wage bill goes entirely to disposable income (equation 21), as the aggregate wage share also includes public jobs (equation 26). Finally, demand for mortgages is a fraction of disposable income, weighted by their exogenous repayment rate (equation 27).

19. $y d=w b+r m_{-1} * m 2 h_{-1}+r b_{-1} * b h_{-1}-\left(r e p_{-1}+r l h_{-1}\right) * l h_{-} 1+f d f+$ $f b+t r-t a x+w b g-c g o v$

20. $c=\alpha_{1} * y d * \frac{e p}{p}+\alpha_{2} * h h_{-1}+\alpha_{3} * m 1 h_{-1}+\alpha_{4} * m 2 h_{-1}+\alpha_{5} * b h_{-1}+\alpha_{6} *$ $e h_{-1}-c_{e}$

21. $\quad w b=\sum_{x=1}^{n} w b_{x}, \forall x \in\{c, k, e\}$

22. $\alpha_{1}=\alpha_{10}-\alpha_{11} * r_{-1}{ }^{\star}-\alpha_{12} * u n_{-1}$

23. $n v h=n v h_{-1}+y d+c g-c$

24. $v h=n v h+l h$

25. $c g=\sum_{x=1}^{n} e^{e s r_{x,-1}} *\left(p e_{x}-p e_{x,-1}\right), \forall x \in\{c, k, e\}$

26. $\Omega=\frac{(w b+w b g)}{y}$

27. $\quad l h=l h_{-1} *(1-r e p)+\phi * y d$ 


\subsection{Commercial Banks}

Banks accommodate the demand for credit, both from firms and households (equation 29), as they accept check and saving deposits (equations 30 and 31) from the latter. In addition, their balance sheets include bills, central bank reserves (based on the demand for deposits), and advances (equation 33). Bank profits are entirely redistributed to households (equation 32). Notice that the notional demand for bills should be distinguished from the actual one. If the former is strictly positive (equation 34), then it is stored in the form of Treasury bills and extra reserves (equation 35), otherwise banks will demand advances from the central bank (equation $36)$.

28. $l f=l f_{c}+l f_{e}+l f_{k}$

29. $l s=l f+l h$

30. $m 1 s=m 1 h$

31. $m 2 s=m 2 h$

32. $f b=\sum_{x=1}^{n} r l_{x,-1} * l f_{x,-1}+\left(r l h_{-1}+r e p_{-1}\right) * l h_{-1}+r b_{-1} * b b_{-1}-r m_{-1} *$ $m 2 s_{-1}-r a_{-1} * a d_{-1}+r h_{-1} *\left(h b d_{-1}+h b d_{-1}{ }^{\star}\right), \forall x \in\{c, k, e\}$

33. $b b_{n o t}=m 1 s+m 2 s-l s-h b d$

34. if $\left(b b_{\text {not }}>0\right) b b=b b_{\text {not }} * \beta$ else $b b=0$

35. if $\left(b b_{\text {not }}>0\right) h b d^{\star}=b b_{\text {not }} *(1-\beta)$ else $h b d^{\star}=0$

36. if $\left(b b_{\text {not }}>0\right)$ ad $=0$ else $a d=-b b_{\text {not }}$

\subsection{Government}

Taxes are levied in accordance with different tax rates on labor, capital, and property income (equation 37). Government expenditure on the productive sectors (including energy, equation 39 ) is completely induced and procyclical (based on the demand for each sector, equations 40 , 41, and 42). Transfers are instead constituted of both an autonomous and induced countercyclical component (based on the unemployment rate, equation 38). Beside these items, government deficit (equation 43) includes interest payments on bills minus taxes and central bank profits. The latter is financed by new issuance of government bills (equation 44).

37. $\operatorname{tax}=\tau_{0}+\tau_{1} * w b+\tau_{2} *\left(r m_{-1} * m 2 h_{-1}+r b_{-1} * b h_{-1}+f d f+f b\right)+\tau_{3} *$ $v h_{-1}$

38. $\operatorname{tr}=\tau_{4}+\tau_{5} * u n_{-1}$ 
39. $g o v=c_{g, c}+c_{g, k}+c_{g, e}$

40. $\quad c_{g, k}=\sigma_{1} *\left(y_{k,-1}\right)$

41. $\quad c_{g, c}=\sigma_{0} *\left(y_{c,-1}\right)$

42. $\quad c_{g, e}=\sigma_{2} *\left(y_{e,-1}\right)$

43. $d e f=g o v+t r+r b_{-1} * b s_{-1}-t a x-f c b+w b g-c g o v$

44. $\quad b s=b s_{-1}+d e f$

\subsection{Portfolio Decisions}

Households demand assets in accordance with Tobinesque principles, represented in the usual matrix form (equation 50). Their portfolio comprises shares - which are supplied on demand by firms and are expressed in real terms (equations 45-49)—government bills, and check deposits. Notice that alongside the financial yields, disposable income is included as a determinant to represent the transaction motive for money demand. Cash is demanded by households based on their expected consumption expenditures (equation 51), while saving deposits act as a buffer (equation 52).

45. $\quad e s r=\sum_{x=1}^{n} e s r_{x}, \forall x \in\{c, k, e\}$

46. $e h r=\sum_{x=1}^{n} e h r_{x}, \forall x \in\{c, k, e\}$

47. $e h r_{x}=e s r_{x}, \forall x \in\{c, k, e\}$

48. $\quad e h=\sum_{x=1}^{n} e h_{x}, \forall x \in\{c, k, e\}$

49. $e h_{x}=e h r_{x} * p e_{x}, \forall x \in\{c, k, e\}$

50. $\quad\left[\begin{array}{c}b h \\ m 1 h \\ p e_{c} e h r_{c} \\ p e_{k} e h r_{k} \\ p e_{e} e h r_{e}\end{array}\right]=\left[\begin{array}{c}\lambda_{10} \\ \lambda_{20} \\ \lambda_{30} \\ \lambda_{40} \\ \lambda_{50}\end{array}\right] * v h_{-1}+\left[\begin{array}{l}\lambda_{11} \lambda_{12} \lambda_{14} \lambda_{15} \lambda_{16} \\ \lambda_{21} \lambda_{22} \lambda_{24} \lambda_{25} \lambda_{26} \\ \lambda_{31} \lambda_{32} \lambda_{34} \lambda_{35} \lambda_{36} \\ \lambda_{41} \lambda_{42} \lambda_{44} \lambda_{45} \lambda_{46} \\ \lambda_{51} \lambda_{52} \lambda_{54} \lambda_{55} \lambda_{56}\end{array}\right] *\left[\begin{array}{c}r b_{-1} \\ r m_{-1} \\ r e_{c,-1} \\ r e_{k,-1} \\ r e_{e,-1}\end{array}\right] * v h_{-1}+\left[\begin{array}{l}\lambda_{13} \\ \lambda_{23} \\ \lambda_{33} \\ \lambda_{43} \\ \lambda_{53}\end{array}\right] * y d_{-1}$

51. $h h=\lambda_{c} * c * \frac{e p}{p}$

52. $\quad m 2 h=v h-h h-m 1 h-b h-e h$

\subsection{Central Bank}

The central bank commits to purchasing all the bills left unsubscribed, in accordance with its function as LLR (equation 53). Cash matches the bills purchased by the monetary authority plus advances minus reserves (both standard and extra, equations 58 and 59). Advances (equation 55) are supplied on demand by the central bank, whilst reserves depend on the legal requirements imposed on banks' deposits (equation 57). Central bank profits are entirely 
transferred to government (equation 56).

53. $\quad b c b=b s-b h-b b$

54. $h s=b c b+a s-\left(h b s+h b s^{\star}\right)+h f$

55. $a s=a d$

56. $f c b=r b_{-1} * b c b_{-1}+r a_{-1} * a s_{-1}-r h_{-1} *\left(h b s_{-1}+h b s_{-1}^{*}\right)$

57. $\quad h b d=\rho 1 * m 1 s_{-1}+\rho 2 * m 2 s_{-1}$

58. $h b s=h b d$

59. $h b s^{\star}=h b d^{\star}$

\subsection{Quantitative Easing}

When the monetary authority conducts OTM with the private sector, it targets a certain share of the existing stock of bills issued (equation 60). We assumed that this share depends on an exogenous target minus the policy rate (equation 61), as it increases when the economy reaches the zero lower bound. For the sake of simplicity, we also assumed that the central bank purchases bills directly from the households, hence both equation (53) and equation (54) for cash and bills demand need to be replaced with equations (62), (63), and (64).

60. $\quad b c b=b s_{-1} *$ vareps

61. vareps $=$ vareps $_{0}-$ varep $_{1} * r^{\star}$

62. $h h=h h+b h-(b s-b b-b c b)$

63. $h s=h h$

64. $b h=b s-b b-b c b$

\subsection{Interest Rates}

The yields in the financial sector behave in accordance with the policy rate set by the central bank plus an exogenous markup (equations 66-71). The only endogenous markup is the one on bills (equation 72), which adjusts to the share of bills purchased by the private sector (equation 73). Yields on corporate securities depend on the ratio between dividends and shares held by the public (equation 65).

65. $r e_{x}=\frac{f d f_{x}}{e h_{x,-1}}, \forall x \in\{c, k, e\}$

66. $r b=r^{\star}+m u b$

67. $r l_{x}=r^{\star}+m u l_{x}, \forall x \in\{c, k, e\}$ 
68. $\quad r l h=r^{\star}+$ mulh

69. $r m=r^{\star}+$ mum

70. $r a=r^{\star}+m u a$

71. $r h=r^{\star}+m u h$

72. $\quad m u b=m u b_{0}-m u b_{1} *\left(b p r-b p r_{-1}\right)$

73. $b p r=\frac{(b h+b b)}{b s}$

\subsection{Labor Market}

Labor demand for each sector is simply defined as the ratio between the demand and labor productivity minus tariffs (equation 75). The workforce grows at an exogenous rate, but it endogenously adjusts to labor demand in the private sector (equation 76). Nominal wages (equations 78,79 , and 80 ) in each sector depend upon both real wages and the adjustment of the actual to the noninflationary rate of unemployment, which is set to zero.

74. $w b_{x}=w * n d_{x}, \forall x \in\{c, k, e\}$

75. $n d_{x}=\frac{\left(y_{x}-c g o v\right)}{p r f_{x}}, \forall x \in\{c, k, e\}$

76. $n s=n s_{-1} *(1+g l)+n u *\left(n d_{-1}-n s_{-1}\right)$

77. $u n=1-\left(\frac{n d}{n s}\right)$

78. $w_{e}=\left(1-\omega_{1} *\left(u_{-1}-\right.\right.$ nun $\left.)\right) *$ ep $* \frac{w_{e,-1}}{p_{-1}}$

79. $w_{c}=\left(1-\omega_{2} *\left(u n_{-1}-n u n\right)\right) * e p * \frac{w_{c,-1}}{p_{-1}}$

80. $w_{k}=\left(1-\omega_{3} *\left(u_{-1}-\right.\right.$ nun $\left.)\right) * e p * \frac{w_{k,-1}}{p_{-1}}$

81. $w=\frac{\left(w_{c}+w_{e}+w_{k}\right)}{3}$

82. $\operatorname{prf}=\frac{\left(\operatorname{prf} f_{c}+p r f_{e}+p r f_{k}\right)}{3}$

\subsection{Prices and Expectations}

Prices in the private sector are determined as a simple markup over unit labor costs (equation 83). The general level of prices (equation 85) includes the costs of public goods and their production costs, given by the labor force in the JG sector (equation 84; more on this in section 4). Inflation expectations are assumed to be adaptive and they are described by equations 87 and 88 .

83. $p f=\left(\frac{w}{p r f}\right) *(1+m u p)$ 
84. $p g=\frac{c g o v}{(p r g * n g)}$

85. $p=p f *\left(1-\left(\frac{\operatorname{cgov}_{-1}}{y_{-1}}\right)\right)+p g *\left(\frac{\operatorname{cgov}_{-1}}{y_{-1}}\right)$

86. $\pi=\left(\frac{p}{p_{-1}}\right)-1$

87. $\quad$ epi $=e p i_{-1}+\psi_{1}+\psi_{2} *\left(\pi_{-1}-e p i_{-1}\right)$

88. $\quad e p=p_{-1} *(1+e p i)$

\subsection{Foreign Sector and Redundant Equation}

As previously mentioned, exports (imports) are an inflow (outflow) only for the consumption sector, as shown in equations 89 and 90 . They are defined in logarithmic form as a function of the nominal exchange rate, foreign (sector c) output, and local prices. Foreign output grows at an exogenous growth rate (equation 91). The exchange rate is fixed and any commercial surplus (deficit) is matched by inflows (outflows) of foreign reserves (equations 92 and 93). The model is closed by the redundant equation (94) that matches the demand and supply for cash by households.

89. $e x=\xi_{0}+\xi_{1} * \log \left(x r_{-1}\right)+\xi_{2} * \log \left(y_{f,-1}\right)+\xi_{3} * \log \left(p_{-1}\right)$

90. $\quad i m=\mu_{0}+\mu_{1} * \log \left(x r_{-1}\right)+\mu_{2} * \log \left(y_{c,-1}\right)+\mu_{3} * \log \left(p_{-1}\right)$

91. $y_{f}=y_{f,-1} *\left(1+g_{f}\right)$

92. $\quad h f=h f_{-1}+t b$

93. $t b=e x-i m$

94. $h h=h s$

\section{FEATURES OF THE EXPERIMENTS}

The shocks to the model are performed by either adding or replacing some of the baseline equations outlined in the previous section. In this sense, several modifications to Godin (2013) and Sawyer and Passarella (2021) were introduced, such as:

i. A JG with an exogenous wage rate and complete absorption of unemployed: This is a closer depiction of the scheme proposed by Minsky (1994). As a matter of fact, in Sawyer and Passarella (2021) the BSE was constrained to a fraction of the unemployed workforce, as wages 
adjusted endogenously. In our simulation we assume instead that: 1) ELR wages are a fraction of wages in the private sector and 2) the ELR program targets all unemployed. As observed above, the latter point is at variance with Nersisyan and Wray (2019), since both skilled and unskilled labor are targeted to cover all types of tasks within the GND (as proposed also by Colacchio and Forges Davanzati [2020]).

ii. A JG that improves energy productivity alongside a reduction in energy demand: Godin (2013) was mainly concerned with government and household expenditure in the energy sector $\left(c_{\mathrm{e}}\right.$ and $c_{\mathrm{g}}$ ). But in order to constrain energy consumption, prevent the rebounding effect endogenously caused by growth in total output, and to stimulate the other productive sectors to expand their output, it is necessary to also intervene in energy productivity (pre). Moreover, an increase in energy efficiency would be the main objective of GND-related publicly guaranteed jobs, as noted earlier. Yet, we discarded the possibility that an ELR scheme improves labor productivity ( $p r f$ ) because the impact that such a scheme may have on a heterogeneous workforce is not clear.

iii. The reduction in the parameters of energy consumption is driven by how many public resources are committed: Godin (2013) simply assumed that parameters in $c_{\mathrm{e}}$ and $c_{\mathrm{g}}\left(\sigma_{3}\right.$ and $\left.\sigma_{2}\right)$ were reduced in accordance with the size of the JG. We assumed instead that this effort depends on the monetary resources committed. This is also to provide a comparison with the scenario of a simple boost in government expenditure.

iv. A scenario with government expenditure is introduced in order to provide a comparison either with the normal JG or the GND JG: In both these cases the reduction in critical parameters is driven by the size of this expenditure, which equals the (hypothetical) dimension of a JG wage bill - that is, as if the government was to introduce transfers to all unemployed persons equal to the JG salary. This is again to make the JG closer to Minsky's (1965) original formulation. 
v. Endogenous government expenditure in the productive sectors is redistributed away from sector e and injected into sector $k$ (scenario 6): A possible way to avoid the recessionary results obtained in the case of the reduction of output's dependent component (as in case of the expenditure in household and government energy consumption) is to compensate for the fall in the endogenous component of government expenditure that shrinks as a consequence of expenditure reduction in sector e. By doing so, the redistribution of output away from the energy sector and toward the other components of output (consumption, widgets, and investment) may take place without output losses.

Once the model ${ }^{5}$ has been run through 100 periods to obtain a baseline (scenario 1), the following scenarios are then performed:

Scenario 2: Minsky-like JG;

Scenario 3: government transfers to unemployed;

Scenario 4: GND-based JG (as in scenario 2, with Godin-like modified with endogenous energy productivity);

Scenario 5: government transfers to unemployed (as in scenario 3) with reduction in energy consumption similar to scenario 4 ; and

Scenario 6: as in scenario 4, but with redistribution of government expenditure.

All the experiments have been introduced as shocks to the baseline model at time 60. The model's new equations can be found at the end of the paper, as well as the parameters used in the simulation. As we did not mean to empirically validate our exercise, the exogenous values are either taken from the literature or adopting reasonable guidelines. Nevertheless, some

\footnotetext{
${ }^{5}$ the. $\mathrm{R}$ code to generate the simulations can be downloaded from: https://github. com/Giutoya/JG_GND
} 
sensitivity analysis was conducted and the results can be found in the appendix.

\section{RESULTS}

The results from the simulation for selected variables (aggregate and sector e output; aggregate consumption; energy consumption from both households and government; aggregate and sector e investment; unemployment; employment; prices; nominal wages; wage share; trade balance; output growth; and deficit/GDP and debt/GDP ratio) are presented in this section as a ratio with respect to their baseline. Since the model does not comprise a physical stock-flow matrix, as in Georgescu-Roegen (1979), Berg, Hartley, and Richters (2015), and Dafermos, Nikolaidi, and Galanis (2018), sector e output and its related variables will be used as proxies to measure energy efficiency. Reducing energy consumption does come with a cost for the economy, as can be observed from figure 1. The difference with the "standard" (scenarios 2 and 3 ) and the "green" measures (scenarios 4 and 5) is that, in spite of the stimulus, total output tends to be lower than the baseline as a result of the endogenous reduction in the parameters household and government energy consumption. This does not take place in scenario 6, as total government spending has been redistributed instead of reduced, thereby maintaining a certain target expenditure on GDP. This is consistent with Godley and Cripps (1983), Carnevali et al. (2019), and in the general tradition of demand-led models. As expected, in figure 2 only the green policies (scenarios 4, 5, and 6) manage to reduce the output of sector e, which may be interpreted as our proxy for measuring the reduction in the environmental impact of the economic activity. Although these last two variables are driven toward zero, output in sector e tends to converge to a lower, yet positive, steady state due to the reduction in energy costs and the subsequent (partial) rebound of the economy. This side effect of the energy efficiency policies can be appreciated by the dynamic of aggregate consumption, which is boosted in all but one scenario (scenario 4). Similar observations apply to both aggregate and sector e investment in figure 3. Looking at labor market behavior in all the experiments, the effect of the ELR scheme clearly emerges in contrast with a cash transfer approach. The unemployment (employment) rate in scenarios 2, 4, and 6 falls (increases) as the BSE is enacted. Although 
scenario 3 displays a similar tendency, its slope tends to diverge with respect the JG scenarios. Scenario 5 is of particular interest: as the government grants transfer to the unemployed workforce, the employment (unemployment) rate immediately rises (falls). However, this reverses in the subsequent periods as the energy-saving policies are progressively put in place, causing workers in sector e to be dismissed and aggregate unemployment to rise above (fall below) the baseline. Eventually, workers are reabsorbed into the private sector given the rebound in the widget sector and recovery in capital goods firms. Given the assumptions made for the labor market, the average nominal wage in the private sector does tend to steadily increase with the exception of that in scenario 5, driving the (long-run) rise in prices of the private goods (figure 4). The reader may point out that this inflationary (albeit mild) outcome contrasts with Minsky (1994), Mosler (1997), and Mitchell (1998) on the JG as the path to price stability. There are two explanations for this puzzle. First, although we postulate that wages in the JG act as a numeraire for the labor market, workers' nominal wages are a function of the unemployment rate, as in Kriesler and Halevi (2016) and Levrero (2019). Hence, cost-induced inflation may arise well before the supply constraints that trigger the demand-induced one. Second, ours is not a business cycle exercise, as we are simply interested in studying the properties - both during the traverse and at its steady state - of the model once a shock is performed. Therefore, depending on the nature of the shock the new values for flows and stocks may permanently deviate from the original ones. Thus, one should not be surprised by the growing tendency in price levels in both the "brown" scenarios (2 and 3), as involuntary employment is progressively eliminated either via the ELR or cash transfers. Nor should one be surprised by the stagnant trend in scenario 5, due to the employment losses in the private sector during the adjustment phase. The focus should go instead to scenarios 4 and 6 , since it is not clear at first which tendency should prevail — the positive one caused by the BSE or the negative one caused by the unemployment in sector e. Given the model's premises, our experiment denotes that a JG scheme has a positive impact on the price levels of private goods in these two scenarios, whilst their slopes are not as steep as that of the Minsky-like scenario. The increase in the wage share under all the alternative scenarios hints that government outlays are channeled almost entirely to consumption, as noted by Nersisyan and Wray (2019). Moreover, they also denote a profit squeeze situation in scenarios 4, 5, and 6 as markups are 
held constant, assigning to our simulation strong wage-led properties (Bhaduri and Marglin 1990). Output tends to grow in all the brown scenarios, as shown in figure 5 , while the sustainable ones present a decoupling condition with respect to the growth rate of the labor force, which is pressured by a tight labor market. As expected, the trade balance deteriorates in all the scenarios that display a higher output in the steady state, with the exception of scenario 6 , whereas in all the other cases it improves when total output is lower. Finally, both the deficit and the debt-to-GDP ratio tend to be higher, although the former exhibits a logarithmic increase as the latter stabilizes at a higher steady state in scenarios 4,5 , and 6 . Consequently, the interest rate burden (the share of interest payment over tax revenues) grows in all the scenarios with respect to the baseline, although at different rates. Table 3 wraps up the results for the main variables.

\section{Figure 1: Output under Alternative Scenarios}

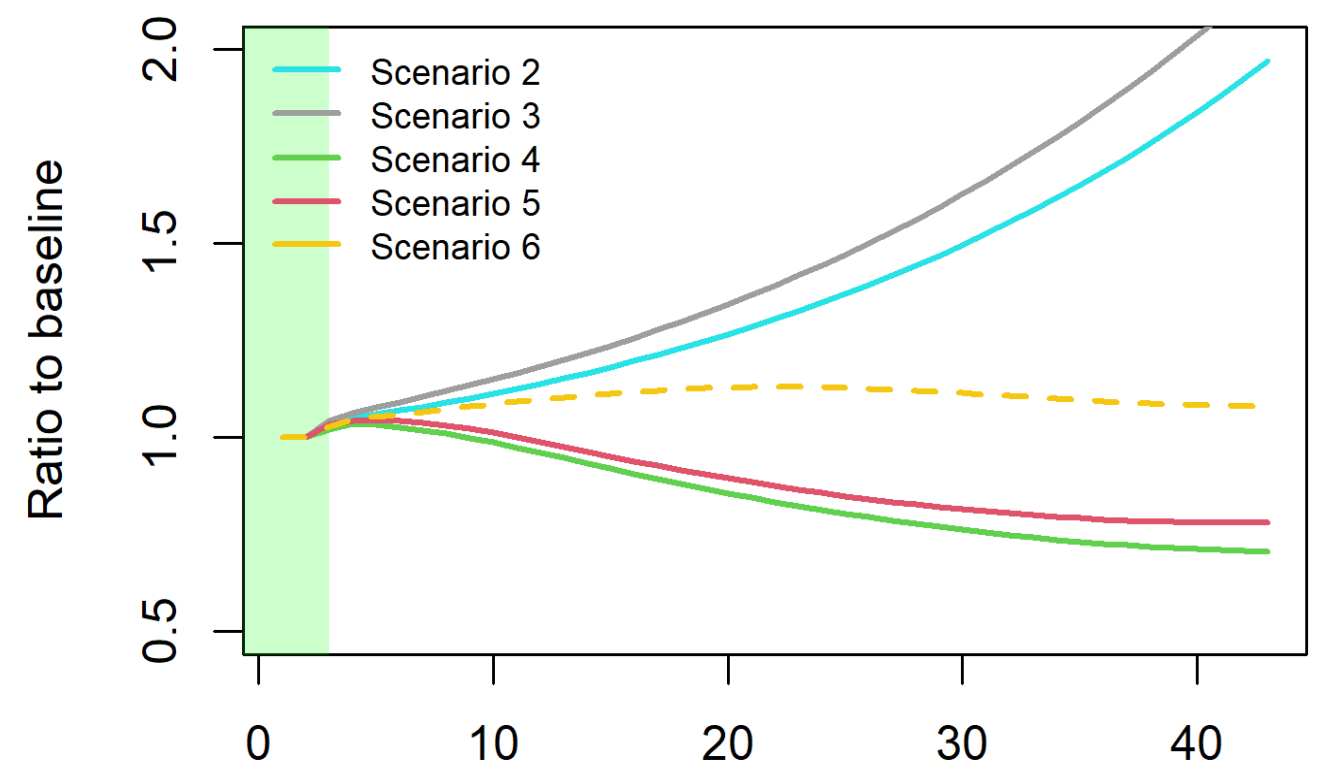

Source: Own elaboration. 
Figure 2: Output in Sector E, Consumption, Households' and Government's Energy Consumption under Alternative Scenarios
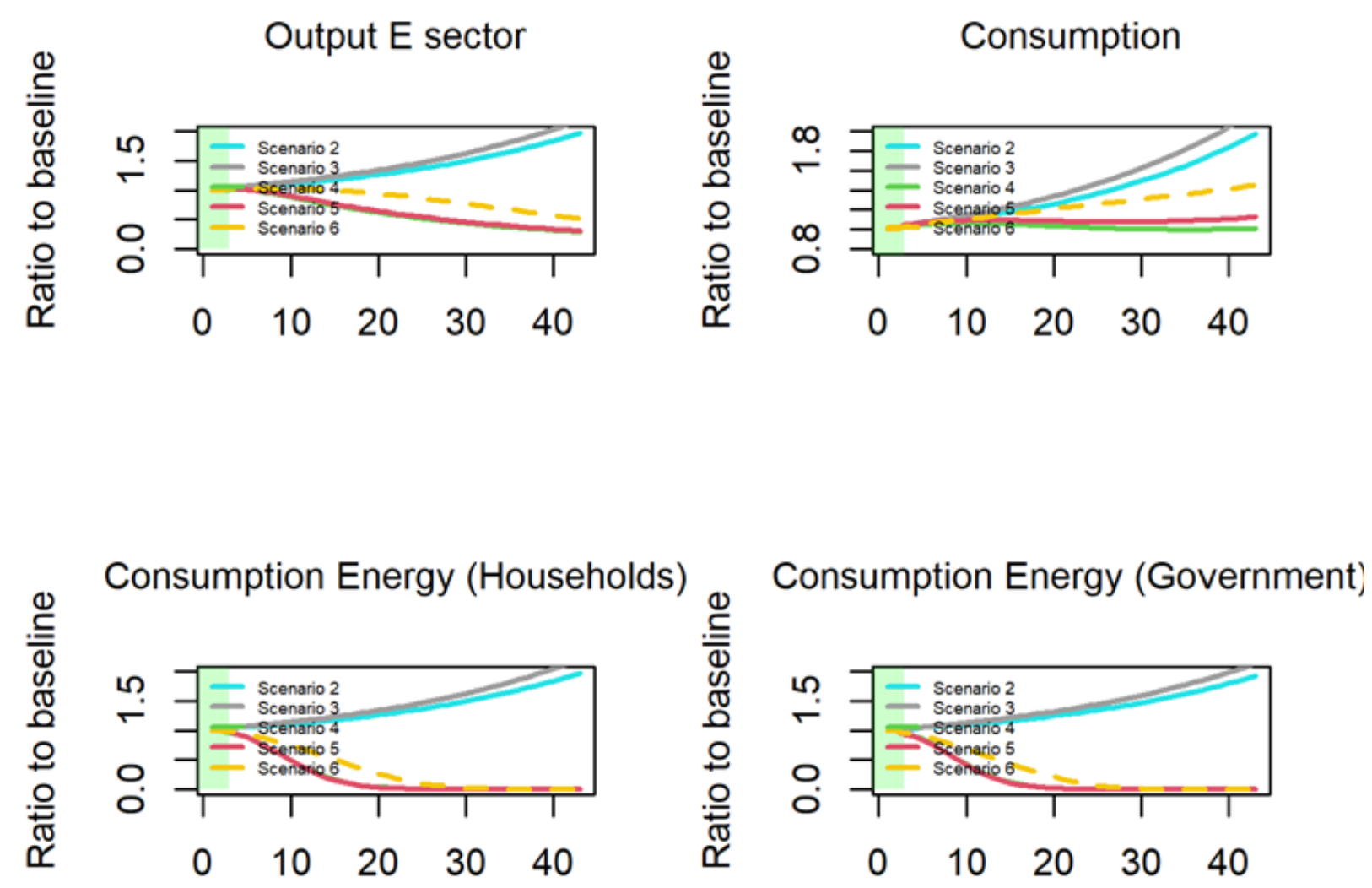

Source: Own elaboration. 
Figure 3: Investment, Energy Investment, Unemployment, and Employment Rate under Alternative Scenarios
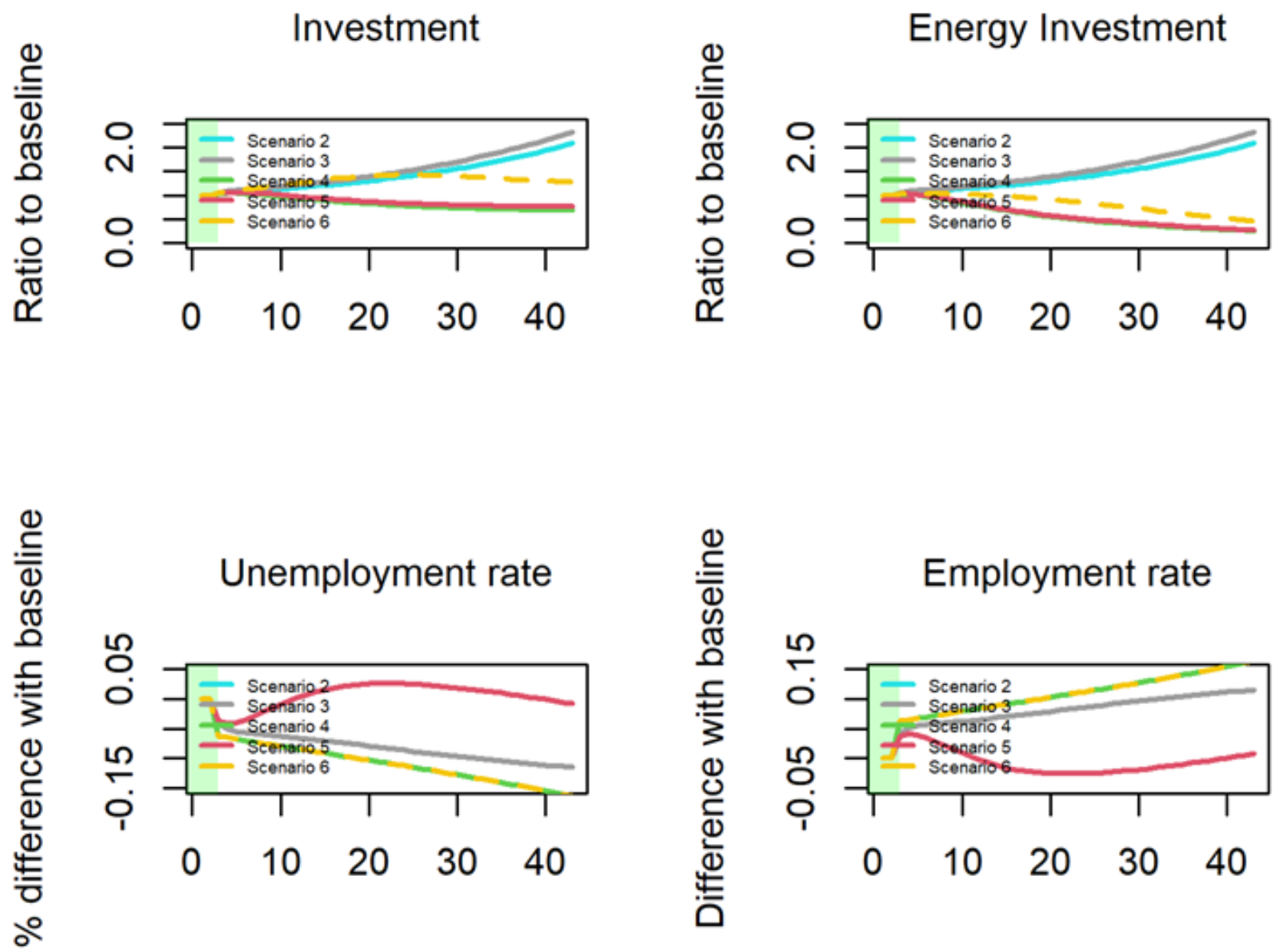
Figure 4: Prices in the Short and Long Run, Average Nominal Wage, and Trade Balance under Alternative Scenarios
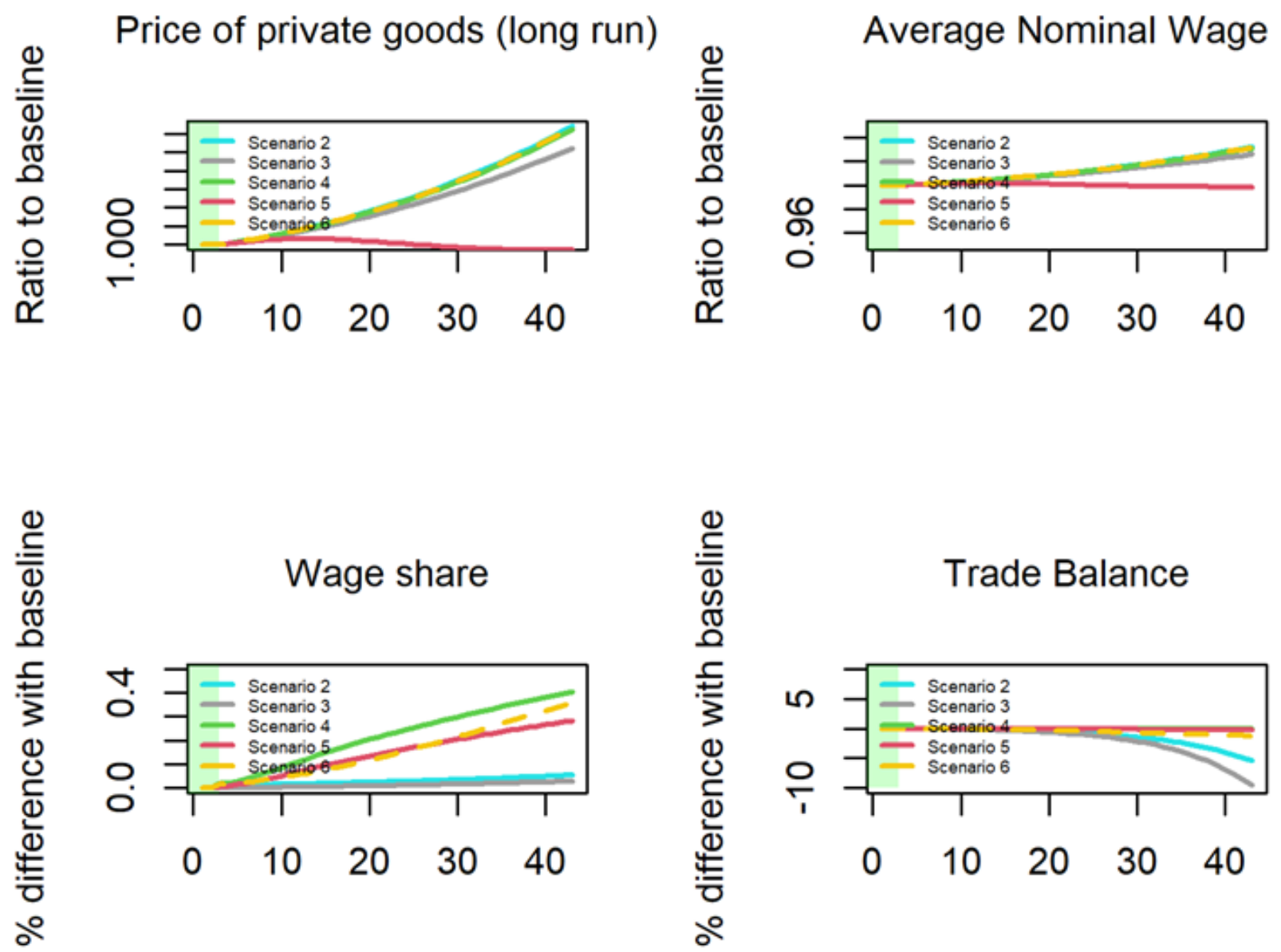
Figure 5: Output Growth, Interest Burden, Deficit-to-GDP Ratio, and Debt-to-GDP Ratio under Alternative Scenarios
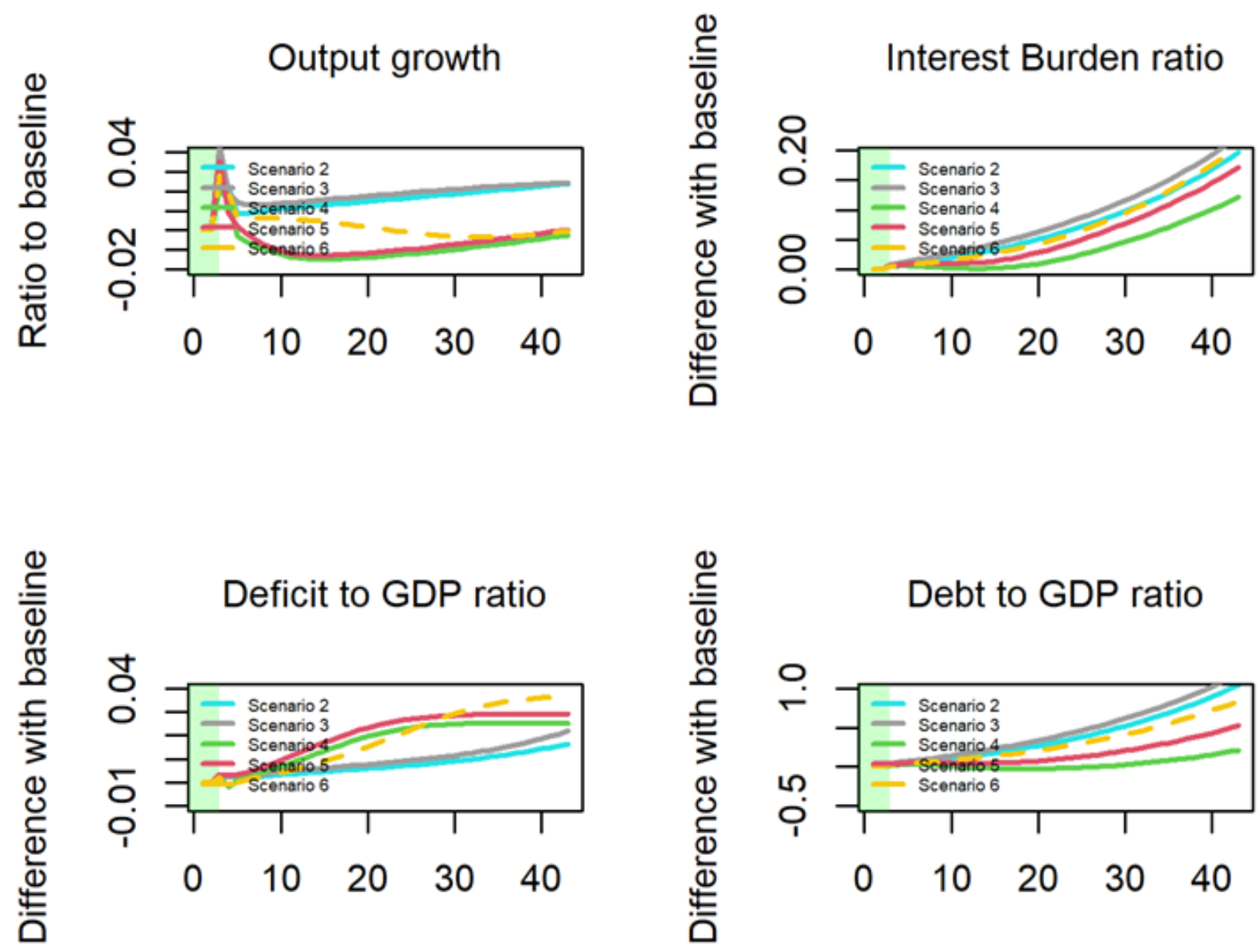

Source: Own elaboration. 
Table 3. Wrap-up of the Results (long-run)

\begin{tabular}{llllll}
\hline & Scenario 2 & Scenario 3 & Scenario 4 & Scenario 5 & Scenario 6 \\
\hline Output & + & + & - & - & + \\
Output e & + & + & - & - & - \\
Investment & + & + & - & - & + \\
Wages & + & + & + & - & + \\
Unemployment & - & - & - & 0 & - \\
Deficit/GDP ratio & + & + & + & + & + \\
Debt/GDP ratio & + & + & + & + & + \\
Trade balance & - & - & 0 & 0 & - \\
Output growth & + & + & 0 & 0 & 0 \\
\hline
\end{tabular}

\section{CONCLUSIONS}

In this paper we investigated the policy package known as "Green New Deal," and in particular its proposal to tackle the problem of involuntary unemployment, namely the employment of last resort scheme inspired by Hyman Minsky (1965, 1968, 1994) and MMT scholars (Mosler 1997; Wray 1998, 2015; Mitchell, Wray, and Watts 2019). After a brief outline of their core ideas, we highlighted some of the weaknesses in their analysis, with respect to both the standard and the GND JG. Since an ambitious plan that aims at improving energy efficiency requires a rigorous estimation of all its components to avoid double counting, as acknowledged also by proponents such as Nersisyan and Wray (2021), the SFC methodology was adopted to implement the scenario analysis of the transition toward a carbon-neutral economy. SFC models have become increasingly popular in the heterodox community and have been crossing paths with both ecological economics to incorporate environment issues and the MMT-related research to test some of its assertions. In particular, for our model we have drawn upon Godin (2013) and Sawyer and Passarella (2021), as we proposed a multisectorial stylized economy with a detailed description of both the financial sector and the monetary policy transmission mechanism. Five combinations of policies designed to either reduce energy demand and/or reduce (alleviate) unemployment were then proposed. The best policy mix to achieve full employment and environmental sustainability appears to be the one in scenario 6 (GND JG + public expenditure 
in capital formation), as it raises aggregate output, investment, and wages while reducing unemployment and total energy consumption without compromising the external balance too much. In turn, neither the pure "brown" (scenarios 2 and 3) nor the pure "green" (scenarios 4 and 5) policies manage to hit the two targets foreseen by the GND, as for the former the rebounding effect is not taken into account whilst for the latter the ELR penalizes the energy sector and the entire economy too much. In short, the GND JG cannot do the "job" alone, but it requires expenditure in the productive sectors. The real advantage of the JG over cash transfers is that it prevents job losses while energy transition is undertaken.

Finally, some observations are in order. First, the ELR scheme simulated in our exercise departs from the traditional BSE mechanism, since endogenous fluctuations are not inspected and the scope of the tasks performed in this scheme goes beyond even the JG put forward by Nersisyan and Wray (2021). In fact, the uncertainties about the short-term length of the program that we pointed out earlier are removed as the program takes on the bulk of the energy efficiency efforts instead of working on secondary projects. Can we still compare it one-to-one to Minsky's (1965) original idea? Certainly not, as it resembles Colacchio and Forges Davanzati's (2020) proposal for the state as "innovator of first resort" when it comes to greening the productive structure. Second, as we are reminded by Kalecki (1943), Epstein (2019), and Vernengo and Perez Caldentey (2020), while there are no real problems with financing the debt for a sovereign country, there are limits to how much a government can push up public debt, politically speaking, and in particular the interest rate burden. For a small, open economy that needs to attract foreign capital, higher interest rates are a necessity even though they imply a redistribution toward financial rentiers. In other words, for these wealthier individuals, the deficit may not be an issue, whereas other social groups may bear this higher burden via reduction in social expenditure, higher taxes, and so on. Third, for the same aforementioned reasons, moving toward a carbon-neutral footprint may trigger even stronger resistance from the industries that are negatively affected by green policies. Any progressive, environmentally friendly coalition should not disregard that energy transition may turn out as a positive-sum game for the economy, as hinted by our model, but it is certainly a zero-sum gain politically speaking. 


\section{REFERENCES}

Aspromourgos, Tony. 2000. "Is an Employer-of-Last-Resort Policy Sustainable? A Review Article." Review of Political Economy 12 (2): 141-55.

BoE (Bank of England). 2020. "HM Treasury and Bank of England Announce Temporary Extension to Ways and Means Facility." News and Publications. Published on April 9. Available at: http://www.bankofengland.co.uk/news/2020/april/hmt-and-boe-announcetemporary-extension-to-ways-and-means-facility.

Barro, Robert J., Xavier Sala-i-Martin, Olivier Jean Blanchard, and Robert E. Hall. 1991. "Convergence Across States and Regions." Brookings Papers on Economic Activity 1991 (1): 107-82.

Berg, Matthew, Brian Hartley, and Oliver Richters. 2015. “A Stock-Flow Consistent InputOutput Model with Applications to Energy Price Shocks, Interest Rates, and Heat Emissions." New Journal of Physics 17 (1): 015011.

Bhaduri, Amit, and Stephen Marglin. 1990. "Unemployment and the Real Wage: The Economic Basis for Contesting Political Ideologies." Cambridge Journal of Economics 14 (4): 375-93.

Carnevali, Emilio, and Matteo Deleidi. 2020. "The Trade-Off Between Inflation and Unemployment in an MMT World: An Open Economy Perspective.” Levy Institute Working Paper No. 973. Annandale-on-Hudson, NY: Levy Economics Institute of Bard College.

Carnevali, Emilio, Matteo Deleidi, Riccardo Pariboni, and Marco Veronese Passarella. 2019. "Stock-Flow Consistent Dynamic Models: Features, Limitations and Developments." In Philip Arestis and Malcolm Sawyer (eds.), Frontiers of Heterodox Macroeconomics. Berlin: Springer.

_ 2021. "Cross-Border Financial Flows and Global Warming in a Two-Area Ecological SFC Model." Socio-Economic Planning Sciences 75 (2): 100819.

Caverzasi, Eugenio, and Antoine Godin. 2013. "Stock-Flow Consistent Modeling Through the Ages.” Levy Institute Working Paper No. 745. Annandale-on-Hudson, NY: Levy Economics Institute of Bard College .

Cimoli, Mario. 1988. "Technological Gaps and Institutional Asymmetries in a North-South Model with a Continuum of Goods." Metroeconomica 39 (3): 245-74. 
Colacchio, Giorgio, and Guglielmo Forges Davanzati. 2020. "Modern Money Theory: A Critical Assessment and a Proposal for the State as Innovator of First Resort." Review of Political Economy 32 (1): 77-98.

Cucignatto, Giacomo. 2021. “Un'analisi Input-Output Del Job Guarantee e Della Strategia Nazionale Per l'idrogeno Nell'economia Italiana.” PhD thesis, Roma Tre University.

Dafermos, Yannis, Maria Nikolaidi, and Giorgos Galanis. 2018. "Climate Change, Financial Stability and Monetary Policy.” Ecological Economics 152: 219-34.

Deleidi, Matteo, Riccardo Pariboni, and Marco Veronese Passarella. 2019. "Supermultiplier, Innovation and the Ecosystem: A Stock-Flow Dynamic Model." Institute for Innovation and Public Purpose Working Paper No. 2019-01. London: University College London.

Ehnts, Dirk H. 2014. “A Simple Macroeconomic Model of a Currency Union with Endogenous Money and Saving-Investment Imbalances." International Journal of Pluralism and Economics Education 5 (3): 279-97.

- 2016. Modern Monetary Theory and European Macroeconomics. Abingdon, UK: Taylor \& Francis.

Epstein, Gerald A. 2019. What's Wrong with Modern Money Theory?: A Policy Critique. Berlin: Springer.

Fetherston, M. J. 1976. "Technical Manual on the CEPG Model" CPES Online Archive, Accessed October 23, 2021. Available at: https://cpes.org.uk/om/items/show/296.

- 1977. "Technical Manual on the CEPG Model 2nd" CPES Online Archive. Accessed October 23, 2021, Available at: https://cpes.org.uk/om/items/show/297.

Georgescu-Roegen, Nicholas. 1971. The Entropy Law and the Economic Process. Cambridge, MA: Harvard University Press.

. 1979. "Energy Analysis and Economic Valuation." Southern Economic Journal 45 (4): 1023-58.

Godin, Antoine. 2013. "Green Jobs for Full Employment, a Stock Flow Consistent Analysis." In Michael J. Murray and Mathew Forstater (eds.), Employment Guarantee Schemes. Berlin: Springer.

_. 2014. "Job Guarantee: A Structuralist Perspective." Revue de La Regulation. Capitalisme, Institutions, Pouvoirs 16 (2): 10988. 
Godley, Wynne. 1999. “Seven Unsustainable Processes.” Levy Institute Strategic Analysis (Special Report). Annandale-on-Hudson, NY: Levy Economics Institute of Bard College.

Godley, Wynne, and Marc Lavoie. 2012. Monetary Economics: An Integrated Approach to Credit, Money, Income, Production and Wealth, 2nd ed. London: Palgrave Macmillan.

Godley, Wynne, and Francis Cripps. 1983. Macroeconomics. London: Fontana.

Graziani, Augusto. 2003. The Monetary Theory of Production. Cambridge, UK: Cambridge University Press.

Hannsgen, Greg. 2020. "MMT in Equations and Diagrams: An Expositional Framework.” In proceedings of the 46th meeting of the Eastern Economic Association, Boston, MA, February 27-March 1.

Jackson, Tim, and Peter A. Victor. 2015. “Does Credit Create a 'Growth Imperative?' A QuasiStationary Economy with Interest-Bearing Debt.” Ecological Economics 120: 32-48.

Jevons, William Stanley. 1865. The Coal Question: An Inquiry Concerning the Progress of the Nation, and the Probable Exhaustion of the Coal-Mines. London: Macmillan.

Kalecki, Michal. 1943. "Political Aspects of Full Employment." Political Quarterly 14 (4): 322-31.

Kaltenbrunner, Annina. 2018. "Financialised Internationalisation and Structural Hierarchies: A Mixed-Method Study of Exchange Rate Determination in Emerging Economies." Cambridge Journal of Economics 42 (5): 1315-41.

Kaltenbrunner, Annina, and Juan Pablo Painceira. 2015. "Developing Countries' Changing Nature of Financial Integration and New Forms of External Vulnerability: The Brazilian Experience." Cambridge Journal of Economics 39 (5): 1281-1306.

Keynes, John Maynard. 1930. Treatise on Money: Pure Theory of Money Vol. I. London: Macmillan.

Knapp, Georg Friedrich. 1924. The State Theory of Money. London: Macmillan.

Kriesler, Peter, and Joseph Halevi. 2016. "Political Aspects of 'Buffer Stock' Employment." In Joseph Halevi, Geoffrey C. Harcourt, Peter Kriesler, and John W. Nevile (eds.), PostKeynesian Essays from down Under Volume II: Essays on Policy and Applied Economics. London: Palgrave Macmillan. 
Lavoie, Marc. 2013. "The Monetary and Fiscal Nexus of Neo-Chartalism: A Friendly Critique." Journal of Economic Issues 47 (1): 1-32.

Lerner, Abba P. 1943. "Functional Finance and the Federal Debt." Social Research 10 (1): 3851.

- 1947. "Money as a Creature of the State." The American Economic Review 37 (2): $312-17$.

Levrero, Enrico Sergio. 2019. "On the Criticisms of and Obstacles to the Employer of Last Resort Policy Proposal.” International Journal of Political Economy 48 (1): 41-59.

Lucas, Robert. 1976. “Macro-Economic Policy Evaluation: A Critique.” Journal of Monetary Economics (Supplementary Series)1 (2): 19-46.

Malthus, Thomas Robert. 1872. An Essay on the Principle of Population. London: J. Johnson.

Minsky, Hyman P. 1965. “The Role of Employment Policy.” Hyman P. Minsky Archive Paper No. 270. Accessed October 23, 2021. Available at:

https://digitalcommons.bard.edu/hm_archive/270

- 1968. "Effects of Shifts of Aggregate Demand Upon Income Distribution." American Journal of Agricultural Economics 50 (2): 328-39.

- 1994. "Full Employment and Economic Growth as Objectives of Economic Policy: Some Thoughts on the Limits of Capitalism.” Hyman P. Minsky Archive Paper No. 44. Accessed October 23, 2021. Available at:

https://digitalcommons.bard.edu/hm_archive/44

—. 2008. Stabilizing an Unstable Economy. New York: McGraw-Hill.

Mitchell, William F. 1998. "The Buffer Stock Employment Model and the NAIRU: The Path to Full Employment.” Journal of Economic Issues 32 (2): 547-55.

Mitchell, William, L. Randall Wray, and Martin Watts. 2019. Macroeconomics. London: Macmillan.

Monasterolo, Irene, Andrea Roventini, and Tim J. Foxon. 2019. "Uncertainty of Climate Policies and Implications for Economics and Finance: An Evolutionary Economics Approach.” Ecological Economics 163: 177-82.

Moore, Basil J. 1988. "The Endogenous Money Supply.” Journal of Post Keynesian Economics 10 (3): 372-85. 
Mosler, Warren. 1997. "Full Employment and Price Stability." Journal of Post Keynesian Economics 20 (2): 167-82.

Naqvi, Syed Ali Asjad. 2015. "Modeling Growth, Distribution, and the Environment in a StockFlow Consistent Framework." WWWforEurope Policy Paper No. 18. Vienna: Austrian Institute of Economic Research.

Nersisyan, Yeva, and L Randall Wray. 2021. “Can We Afford the Green New Deal?" Journal of Post Keynesian Economics 44 (1): 68-88.

— 2019. "How to Pay for the Green New Deal." Levy Institute Working Paper No. 931. Annandale-on-Hudson, NY: Levy Economics Institute of Bard College.

Nikiforos, Michalis, and Gennaro Zezza. 2017. "Stock-Flow Consistent Macroeconomic Models: A Survey." Journal of Economic Surveys 31 (5): 1204-39.

Ocampo, José Antonio, Codrina Rada, and Lance Taylor. 2009. Growth and Policy in Developing Countries: A Structuralist Approach. New York: Columbia University Press.

Powell, Jerome H. 2020. "Speech by Chair Powell on New Economic Challenges and the Fed's Monetary Policy Review." Board of Governors of the Federal Reserve System. Published on August 27, 2020. Available at: https://www.federalreserve.gov/newsevents/speech/powell20200827a.htm.

Prates, Daniela. 2020. "Beyond Modern Money Theory: A Post-Keynesian Approach to the Currency Hierarchy, Monetary Sovereignty, and Policy Space." Review of Keynesian Economics 8 (4): 494-511.

Prebisch, Raul. 1949. "El Desarrollo Económico de La América Latina y Algunos de Sus Principales Problemas." El trimestre económico 16 (63): 347-431.

Rochon, Louis-Philippe, and Matias Vernengo 2003. "State Money and the Real World: Or Chartalism and Its Discontents." Journal of Post Keynesian Economics 26 (1): 57-67.

Sawyer, Malcolm. 2003. "Employer of Last Resort: Could It Deliver Full Employment and Price Stability?" Journal of Economic Issues 37 (4): 881-907.

Sawyer, Malcolm, and Marco Veronese Passarella. 2021. "A Comprehensive Comparison of Fiscal and Monetary Policies: A Comparative Dynamics Approach." Structural Change and Economic Dynamics 59 (4): 384-404. 
Seccareccia, Mario. 2004. "What Type of Full Employment? A Critical Evaluation of 'Government as the Employer of Last Resort' Policy Proposal." Investigacion Economica 63 (247): 15-43.

Sorrell, Steve, John Dimitropoulos, Lester Hunt, David Broadstock, Grant Allan, Michelle Gilmartin, Peter McGregor, Kim Swales, Karen Turner, Matt Sommerville, and Dennis Anderson. 2007. "The Rebound Effect: An Assessment of the Evidence for EconomyWide Energy Savings from Improved Energy Efficiency." UK Energy Research Centre's Technology and Policy Assessment Research Report. London: UK Energy Research Centre.

Vernengo, Matias, and Esteban Perez Caldentey. 2020. "Modern Money Theory (MMT) in the Tropics: Functional Finance in Developing Countries." Challenge 63 (6): 332-48.

Vivanco, David Font, René Kemp, and Ester van der Voet. 2016. "How to Deal with the Rebound Effect? A Policy-Oriented Approach.” Energy Policy 94: 114-25.

Wray, L. Randall.2004. Credit and State Theories of Money: The Contributions of A. Mitchell Innes. Cheltenham, UK: Edward Elgar Publishing.

- 2015. Modern Money Theory: A Primer on Macroeconomics for Sovereign Monetary Systems. Berlin: Springer.

— 1998. Understanding Modern Money. Cheltenham, UK: Edward Elgar Publishing.

Wray, L. Randall, Flavia Dantas, Scott Fullwiler, Pavlina R. Tcherneva, and Stephanie A. Kelton. 2018. "Public Service Employment: A Path to Full Employment." Research Project Report. Annandale-on-Hudson, NY: Levy Economics Institute of Bard College.

Zezza, Gennaro, and Francesco Zezza. 2019. "On the Design of Empirical Stock-FlowConsistent Models.” Levy Institute Working Paper No. 913. Annandale-on-Hudson, NY: Levy Economics Institute of Bard College. 


\section{APPENDIX 1. PARAMETERS AND INITIAL VALUES}

Table 4. Parameters and Initial Values

\begin{tabular}{|c|c|c|}
\hline Variables and parameters of the economy & Symbols & Baseline \\
\hline Energy productivity & pre & 2 \\
\hline Dependent component of consumption spending on energy & $\sigma_{3}$ & 0.055 \\
\hline capital-output ratio of the sector $\mathrm{x}$ & $\kappa_{\mathrm{x}}$ & 0.8 \\
\hline Depreciation rate & $\delta$ & 0.1 \\
\hline Reaction speed of adjustment of capital to its target value sector c & $\gamma_{\mathrm{x}}$ & 0.15 \\
\hline Mark-up: loans' interest rate sector $\mathrm{x}$ & $m u l_{\mathrm{x}}$ & 0.02 \\
\hline Profit retention rate sector $\mathrm{x}$ & theta $a_{\mathrm{x}}$ & 0.25 \\
\hline Target percentage of investment to be funded by share issues & chi & 0.1 \\
\hline Mark-up: saving deposits' return rate & mum & 0.25 \\
\hline Coefficient of bills' return rate & $m u b_{0}$ & 0.25 \\
\hline Coefficient of bills' return rate & $m u b_{1}$ & 0.25 \\
\hline Repayment rate on mortgages & rep & 0.01 \\
\hline Mark-up: interest rate on mortgages & mulh & 0.02 \\
\hline Autonomous component of propensity to consume & $\alpha_{1} 0$ & 0.75 \\
\hline Propensity to consume out of wealth: cash & $\alpha_{2}$ & 0.15 \\
\hline Propensity to consume out of wealth: cheque deposits & $\alpha_{3}$ & 0.1 \\
\hline Propensity to consume out of wealth: saving deposits & $\alpha_{4}$ & 0.05 \\
\hline Propensity to consume out of wealth: bills & $\alpha_{5}$ & 0.01 \\
\hline Propensity to consume out of wealth: shares and other firms' securities & $\alpha_{6}$ & 0.01 \\
\hline Sensitivity of propensity to consume to interest rate & $\alpha 11$ & 2 \\
\hline Sensitivity of propensity to consume to unemployment rate & $\alpha 12$ & 0.05 \\
\hline Policy rate & $r \star$ & 0.0145 \\
\hline Mortgages to disposable income ratio & $\phi$ & 0.03 \\
\hline Mark-up: CB advances' return rate & тиа & 0.005 \\
\hline Mark-up: reserves' return rate & muh & 0 \\
\hline Share of notional bills held as bills by banks & $\beta$ & 0.5 \\
\hline Autonomous component of tax revenue (shock) & $\tau_{0}$ & 0 \\
\hline Tax rate on labor income & $\tau_{1}$ & 0.2 \\
\hline Tax rate on capital income & $\tau_{2}$ & 0.2 \\
\hline Tax revenue rate on wealth & $\tau_{3}$ & $1 / 200$ \\
\hline Other transfers & $\tau_{4}$ & 2 \\
\hline Unemployment benefits (relative to unemployment rate) & $\tau_{5}$ & 5 \\
\hline Dependent component of government spending & $\sigma_{1}$ & 0.1 \\
\hline Autonomous component of government spending & $\sigma_{0}$ & 0.1 \\
\hline Dependent component of government spending on energy & $\sigma_{2}$ & 0.1 \\
\hline Parameter in portfolio equation of bills & $\lambda 10$ & 0.1 \\
\hline Parameter in portfolio equation of bills & $\lambda 11$ & 0.2 \\
\hline Parameter in portfolio equation of bills & $\lambda 12$ & -0.1 \\
\hline Parameter in portfolio equation of bills & $\lambda 13$ & -0.1 \\
\hline Parameter in portfolio equation of bills & $\lambda 14$ & 0 \\
\hline Parameter in portfolio equation of bills & $\lambda 15$ & 0 \\
\hline Parameter in portfolio equation of bills & $\lambda 16$ & 0 \\
\hline Parameter in portfolio equation of cheque deposits & 220 & 0.4 \\
\hline
\end{tabular}




\begin{tabular}{|c|c|c|}
\hline Variables and parameters of the economy & Symbols & Baseline \\
\hline Parameter in portfolio equation of cheque deposits & $\lambda 21$ & -0.1 \\
\hline Parameter in portfolio equation of cheque deposits & 222 & -0.1 \\
\hline Parameter in portfolio equation of cheque deposits & 223 & 0.2 \\
\hline Parameter in portfolio equation of cheque deposits & 224 & 0 \\
\hline Parameter in portfolio equation of cheque deposits & $\lambda 25$ & 0 \\
\hline Parameter in portfolio equation of cheque deposits & 226 & 0 \\
\hline Parameter in portfolio equation of c firms' securities & 230 & 0.033333333 \\
\hline Parameter in portfolio equation of c firms' securities & 231 & 0 \\
\hline Parameter in portfolio equation of c firms' securities & 232 & 0 \\
\hline Parameter in portfolio equation of c firms' securities & 233 & 0 \\
\hline Parameter in portfolio equation of c firms' securities & 234 & 0 \\
\hline Parameter in portfolio equation of c firms' securities & 235 & 0 \\
\hline Parameter in portfolio equation of c firms' securities & 236 & 0 \\
\hline Parameter in portfolio equation of $\mathrm{k}$ firms' securities & $\lambda 40$ & 0.033333333 \\
\hline Parameter in portfolio equation of $\mathrm{k}$ firms' securities & $\lambda 41$ & 0 \\
\hline Parameter in portfolio equation of $\mathrm{k}$ firms' securities & $\lambda 42$ & 0 \\
\hline Parameter in portfolio equation of $\mathrm{k}$ firms' securities & $\lambda 43$ & 0 \\
\hline Parameter in portfolio equation of $\mathrm{k}$ firms' securities & $\lambda 44$ & 0 \\
\hline Parameter in portfolio equation of $\mathrm{k}$ firms' securities & $\lambda 45$ & 0 \\
\hline Parameter in portfolio equation of $\mathrm{k}$ firms' securities & $\lambda 46$ & 0 \\
\hline Parameter in portfolio equation of e firms' securities & 250 & 0.033333333 \\
\hline Parameter in portfolio equation of e firms' securities & 251 & 0 \\
\hline Parameter in portfolio equation of e firms' securities & 252 & 0 \\
\hline Parameter in portfolio equation of e firms' securities & 253 & 0 \\
\hline Parameter in portfolio equation of e firms' securities & 254 & 0 \\
\hline Parameter in portfolio equation of e firms' securities & 255 & 0 \\
\hline Parameter in portfolio equation of e firms' securities & 256 & 0 \\
\hline Cash to consumption ratio & $\lambda_{\mathrm{c}}$ & 0.18 \\
\hline Reserves to cheque deposits parameter & $\rho 1$ & 0.025 \\
\hline Reserves to saving deposits parameter & $\rho 2$ & 0.005 \\
\hline Autonomous component of target share of bills held by $\mathrm{CB}$ & vareps $_{0}$ & 1 \\
\hline Sensitivity of target share of bills to interest rate & vareps $_{1}$ & 0.1 \\
\hline Labor Productivity in sector e & $p r f_{\mathrm{e}}$ & 2 \\
\hline Labor Productivity in sector c & $p r f_{\mathrm{c}}$ & 0.5 \\
\hline Labor Productivity in sector $\mathrm{k}$ & $p r f_{\mathrm{k}}$ & 0.5 \\
\hline Structural rate of growth of labor force & $g l$ & 0.03 \\
\hline Speed of adjustment of labor supply to labor demand & nu & 0.2 \\
\hline PC coefficient: speed of adjustment of un to nun sector e & $\omega_{1}$ & 0.01 \\
\hline PC coefficient: speed of adjustment of un to nun sector c & $\omega_{2}$ & 0.005 \\
\hline PC coefficient: speed of adjustment of un to nun sector $\mathrm{k}$ & $\omega_{3}$ & 0.005 \\
\hline Mark-up over labor cost & mup & 0.163 \\
\hline Labor productivity in government sector & prg & 0.75 \\
\hline Coefficient of price expectations function & $\psi_{1}$ & 0 \\
\hline Coefficient of price expectations function & $\psi_{2}$ & 0.01 \\
\hline Parameter in export equation & $\xi_{0}$ & -3.1 \\
\hline Parameter in export equation & $\xi_{1}$ & 0.01 \\
\hline Parameter in export equation & $\xi_{2}$ & 0.01 \\
\hline
\end{tabular}




\begin{tabular}{|l|l|l|}
\hline Variables and parameters of the economy & Symbols & Baseline \\
\hline Parameter in export equation & $\xi_{3}$ & 0.01 \\
Parameter in import equation & $\mu_{0}$ & -3.1 \\
Parameter in import equation & $\mu_{1}$ & 0.01 \\
Parameter in import equation & $\mu_{2}$ & 0.01 \\
Parameter in import equation & $\mu_{3}$ & 0.01 \\
Foreign income growth & $g_{\mathrm{f}}$ & 0.03 \\
Government wage rate to private sector wage rate & $\rho_{\mathrm{g}}$ & 0.3 \\
Speed of adjustment of JG size to market conditions & $\gamma_{\mathrm{g}}$ & 1 \\
Parameter in the loss function of energy consumption & $\zeta$ & 0.01 \\
\hline
\end{tabular}




\section{APPENDIX 2. EQUATIONS OF THE SCENARIOS}

\section{Scenario 2}

This is the scenario in which a simple employment guarantee scheme is implemented. Closely resembling Minsky $(1965,1968,1994)$, the wage paid in this program is set below the current prevailing wage in the private sector, while workers that do not find a job in private industry are hired in the JG workforce. Part of the scheme is assumed to be financed by tariffs levied on households.

95. $n n=n s-n d$

96. $w g=\rho_{g} * w$

97. $n g=n g_{-1}+\gamma_{g} *\left(n n-n g_{-1}\right), \gamma_{g}=1$

98. $\quad w b g=w g * n g$

99. $\quad \operatorname{cgov}=\min \left(\operatorname{alpha} a_{g}\right.$ c, wbg)

\section{Scenario 3}

Under this scenario, unemployment benefits are distributed to all workers that do not find a job in the private sector.

100. $\tau_{4}=n n * w g$

101. $\tau_{5}=0$

\section{Scenario 4}

In addition to the equation in scenario 2 , this experiment introduces the loss function for both household and government energy expenditure and the gain function for energy productivity in the private sector. The intuition behind this choice is that the employment guarantee scheme targets energy efficiency, as it reduces the need for energy by both the private and public sector.

102. $\sigma_{2}=(1-w b g * \zeta) * \sigma_{2}$

103. $\sigma_{3}=(1-w b g * \zeta) * \sigma_{3}$

104. pre $=(1+w b g * \zeta) *$ pre 


\section{Scenario 5}

105. $\sigma_{2}=\left(1-\tau_{4} * \zeta\right) * \sigma_{2}$

106. $\sigma_{3}=\left(1-\tau_{4} * \zeta\right) * \sigma_{3}$

107. pre $=\left(1+\tau_{4} * \zeta\right) *$ pre

\section{Scenario 6}

In this scenario, government expenditure in sector k depends also upon the endogenous shift of expenditure from sector e.

108. $c_{g} k=\sigma_{1} *\left(y_{k,-1}\right)+\left(0.1-\sigma_{2}\right) *\left(y_{e,-1}\right)$ 